\title{
Zuckerman's "Blah-blah Blah-blah Blah": a blow to mimesis, a key to irony
}

\section{Arnaud Schmitt}

\section{(2) OpenEdition}

\section{Journals}

Electronic version

URL: https://journals.openedition.org/ejas/7353

DOI: $10.4000 /$ ejas. 7353

ISSN: 1991-9336

Publisher

European Association for American Studies

\section{Electronic reference}

Arnaud Schmitt, "Zuckerman's "Blah-blah Blah-blah Blah": a blow to mimesis, a key to irony", European journal of American studies [Online], 3-3 | 2008, document 7, Online since 15 December 2008,

connection on 08 July 2021. URL: http://journals.openedition.org/ejas/7353 ; DOI: https://doi.org/

10.4000/ejas.7353

This text was automatically generated on 8 July 2021.

Creative Commons License 


\title{
Zuckerman's "Blah-blah Blah-blah Blah": a blow to mimesis, a key to irony
}

\author{
Arnaud Schmitt
}

1 Philip Roth's American trilogy ${ }^{1}$ is indeed a poignant description of seminal periods of contemporary America. Reading these three outstanding novels, one feels entitled to use the fictional data included to improve or modify one's knowledge of crucial events such as the Vietnam War, McCarthyism or Clinton's peculiar second term. And this is roughly how this work has been depicted in most reviews, as a powerful "mimetic feast." Today, Roth's talent seems to lie mainly in his ability to create a fictional world which is both fascinating and extremely similar to reality. This may come as a surprise if one remembers that the same author had quite a fling with the postmodern at the end of the 1980's and the beginning of the 1990's, particularly in books like The Counterlife or Operation Shylock. Those experiments garnered criticism, but everything seems to have been forgotten since the author is apparently back on the right track, the mimetic track.

Zuckerman's narratological autobiography

2 There are nevertheless a few things that should be considered, among which is Zuckerman's return. Nathan Zuckerman appeared for the first time in My Life as a Man in 1974. Roth has used him nine times since. Yet his first appearance is worth mentioning: Nathan is not just a simple character but both character and narrator of an "embedded narrative."2 My Life as a Man is composed of three narratives; the first one is narrated by Zuckerman, who becomes just a simple character in the second one, the narrator of the third part being Tarnopol, who eventually turns out to be the narrator of the primary narrative, ${ }^{3}$ and retrospectively the author of the first two pieces. Zuckerman is Tarnopol's creation. Thus, the former didn't seem to have such a great future in Roth's fictional world. In fact, his first biographical outline is slightly hazy:

As he did in "Courting Disaster," the second of the "Useful Fictions" in My Life as a Man, Roth again alters aspects of Zuckerman's life and background to offer still a different "legend of the self." In Zuckerman Bound Nathan was born and reared in 
Camden, New Jersey, not Newark; his father is a chiropodist, not a "shoedog"; he now has a younger brother, Henry, instead of an older brother, Sherman, or a sister, Sonia; he has attended the University of Chicago, not a small liberal arts college; he is a writer, not a teacher; and his three marriages, all ending in divorce, have been to exemplary women, as recalled (not dramatized) in The Anatomy Lesson. But Zuckerman is nonetheless recognizable as a character (Halio, 214).

Nathan Zuckerman resurfaces in The Ghost Writer, the first part of what will turn out to be a tetralogy (or a trilogy plus epilogue as the Penguin paperback edition advertises), Zuckerman Bound. Nathan is the first-person narrator ${ }^{4}$ of the primary narrative, his own recollection of a one-night stay at the home of the great American writer, E.I Lonoff, back when Nathan was in his early twenties. (Zuckerman, at the time of narration, is supposedly twenty years older.)

4 Putting his character in the narrating seat allowed Roth to bring him to the fore with force, giving him more authority. Indeed, The Ghost Writer's narrating voice is more mature, even self-ironical. Actually, Thomas Pughe noted that Nathan's voice in the first novel of the tetralogy makes him sound like "a wiser man than the writer we encounter in the subsequent novels, perhaps with the exception of The Counterlife" (Pughe 86). By losing his narrating control in the two subsequent novels, Nathan seems at the same time to lose control over his life. In Zuckerman Unbound and The Anatomy Lesson he is just a puppet in the hands of a less than peaceful fate.

Even if narration in Zuckerman Bound is seemingly less complex than in My Life as a Man, it is an unstable process, related to questions of identity, authority and power, and in this specific way, it foreshadows the main themes of the American trilogy.

6 Furthermore, one of the main functions of the tetralogy is to define Zuckerman as an author, not just a narrator or a character. Zuckerman Bound is definitely a portrait of the artist: first a self-portrait, then a portrait of the artist in the clutches of a "noisy and distracting mass culture" (Franzen 6).

7 In his notorious next novel, The Counterlife, Roth uses the authorial identity of his character to deconstruct any idea of centrality, unity and stability. Zuckerman is the overt narrator of some chapters, or - more precisely - the author, because these chapters are supposed to be a transcript of his writing. But he is missing in other chapters, simply because he is dead. They are narrated by an undeclared narrator. The Counterlife offers a wide range of narrative devices, but mostly a heterogeneous whole, since the different chapters contradict each other: authorial voices, a series of primary and embedded narratives (the two kinds merging in the end), narration from beyond the grave, free indirect speech through Henry (Nathan's brother). Who is dead? Henry or Nathan? Ultimately, who is narrating? It is easy to understand that The Counterlife doesn't aim at answering those questions with certainty, the book's energy coming from its uncertainty, its countertexts. Nathan can be perceived as either a tyrannical narrator or, on the other hand, the victim of a vicious author. Whatever the angle from which the reader chooses to look at it, The Counterlife describes a "text-eat-text world" (Danziger 19) and Zuckerman is Roth's perfect postmodern tool.

8 The Counterlife and three of Roth's four following books (The Facts, Deception and Operation Shylock) have one thing in common: they represent Roth's most daring metafictional venture. At that time, the author seemed keen on putting the emphasis more on the way the story was told (diegesis) than on what it was telling (mimesis) - or, to put it differently, the way the story was told was the story. 
9 The end of the 1980's and the beginning of the 1990's epitomize Roth's experimental period. But even then, even if the novels didn't seem to be totally coherent in a traditional way, he was most of all an outstanding creator of linguistic energy, chaotic energy, by means of superbly antagonistic voices. Although these voices don't seem to be leading anywhere, they represent moments of mere aesthetic flamboyance. Roth has never been a minimalist. At his postmodern best, he created contradictory linguistically-dynamic books. But after all these meta-excesses, Roth gave the impression of being drawn to a less complex style of narration.

Zuckerman the writer

10 After having taken Zuckerman to such meta-heights, Roth appeared to have reached a dead-end as to what to do with his character - he used him for what seemed to be the last time in The Facts, as the censor of his own autobiography. In order to up the ante, Roth decided to cast Zuckerman aside and to include himself in his fiction: "To compromise some "character" doesn't get me where I want to be. What heats things up is compromising me" (Roth, Deception 177). This is what he did in Operation Shylock. He didn't summon up Zuckerman for his next novel either - Sabbath's Theater, his nineties' version of Portnoy's Complaint. It seemed difficult to recycle a character that had already been used in so many different ways. Zuckerman was washed out, ready for oblivion. ${ }^{5}$

11 Yet, quite surprisingly, Roth finds him something to do in his American trilogy. At first glance, Zuckerman's situation has changed altogether. Roth has taught him humility; his voice appears more withdrawn. He is only occasionally a part of the story told, which is nevertheless always centered on a different character - someone from his past for American Pastoral and I Married a Communist. Nathan is no longer someone who acts but someone who listens and remembers, thus becoming a remote figure. It would be odd to dub the American trilogy a Zuckerman book in the same way The Ghost Writer and the three books that followed were called Zuckerman Bound. To a newcomer to Roth's fiction, Zuckerman in the trilogy (maybe with the exception of The Human Stain) doesn't seem to be as indispensable. The real attraction is a heartrending description of a painful period seen through the eyes of a character who experienced it, at his own expense.

12 But if one takes a closer look, and this is what academics are supposed to do, the fictional situation is much more intricate. This newfound humility is partly feigned, his control over every aspect of the fabula both obvious and discreet. Actually, Zuckerman, as mentioned above, is less important as a character than he used to be. In American Pastoral, he is the narrator of the primary narrative - tales from his old age, his memories of Swede Levov, his childhood idol, and his chance encounter with Swede's brother, Jerry - in which is embedded what turns out to be an imaginary narrative ${ }^{6}$ (the major part of the content of the novel, Swede's life as imagined and narrated by Zuckerman himself, though he is not "actant" in this part). The next two novels offer a similar pattern. In I Married a Communist and The Human Stain, Nathan remains more or less in the background. He acts as a witness, who sometimes has to find a second and more reliable witness (for instance, Murray Ringold in I Married a Communist, with whom he conducts "memory sessions") to fill in the numerous gaps of his ailing memory.

Contrary to Zuckerman Bound, Nathan is more a narrating-I than a narrated-I. He sometimes is an imagining-I (American Pastoral) or a remembering-I (I Married a Communist), and sometimes he is both (The Human Stain). In nine years, he went from 
protagonist and occasional narrator to tenured narrator but "deutéragoniste."8 Zuckerman is now more a voice than anything else; the fact that one speaks implies that one perceives, so Nathan is obviously a perceiver who tries to offer his perception of others' perception, Levov's, Ringold's, Coleman's).

Choosing a writer as character very often means that the author is ready to offer his reader some deep thinking on the pangs of creation, on the figure of the author in the world or to play a game of identity that postmodern addicts relish; and in a way this is what Roth did with Zuckerman Bound and The Counterlife. An author can even include himself/herself in a novel to play the role of the writer (Roth in Operation Shylock or Fowles's apparition at the end of The French Lieutenant's Woman, to give two examples among many). But choosing a writer as a narrator is a totally different commitment with formal consequences. Narration becomes a protean act. Indeed, the narrator is then a fictitious author who, for instance, is writing his own autobiography. Furthermore, in Roth's case, this narrator-author-character can strongly resemble the image of the empirical author the reader created for himself/herself, based on some biographical data available in newspapers, magazines or Roth's own autobiographical writings. Thus, the reader knows that in the past this very same author enjoyed clouding the authorial issue and casting doubts in his fiction and auto-fiction on the identity of his characters, but mostly on the identity of the helmsman, the narrator. This is the American trilogy's background, in which narration appears less complex; however, for the reader who is willing to interrogate the source of his information and the identity of the person with whom he has signed a reading contract, complexity and multiple-subjectivity are still very much relevant.

As most people know, writing fiction doesn't mean writing the way a journalist does,

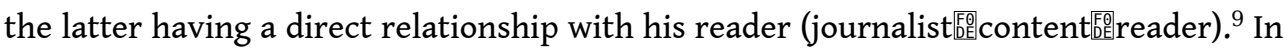
the case of fiction, the relationship is much more sophisticated (Martin, 154). Above all, an author is someone who narrates: "Narrating is something completely different from writing; the distinction of the former is its indirectness" (Mann in Cohn 132). This is what Dorrit Cohn calls "the disjunctive model" (Mann in Cohn 126). The author is different from the narrator, whether the latter is declared or not, personalized or nonpersonalized.

However, what Roth has done with Zuckerman is quite unique in the history of literature. The fact of creating a kind of alter ego - an official narrator or a characterauthor-narrator - is not something deeply original, but the combination of the three through the years makes Roth a pioneer of characterization.

17 He hasn't simply invented a double; he has imagined the absolute double since Zuckerman is quite simply the author of American Pastoral, I Married a Communist and The Human Stain. This assertion must be clarified. The American trilogy does not only propose a fictional mimesis. It does more than that: it presents itself as textual mimesis: it is the mimesis of the diegesis written by Zuckerman. The concept of make-believe here revolves around the idea that Roth has written a book supposedly written by Zuckerman. To be precise, Roth is not really or not only the author of the book: he is first and foremost the creator of the author of the book. What makes it even more complicated is that Zuckerman is not an occasional author. He has his own biographical background familiar to Roth's faithful readers and is quite experienced as an author. $\mathrm{He}$ has an impressive bibliography (The Ghost Writer, potentially Zuckerman Unbound and The Anatomy Lesson, ${ }^{10}$ parts or the whole of The Counterlife according to one's 
interpretative strategy, and then the American trilogy). Roth's voice is actually, most of the time, Zuckerman's. Roth's style is an imitation of what Roth thinks Zuckerman's should be ${ }^{11}$ :

Between the author and the language of the work there is no immediate relationship, as there is between a speaker and what he says. [...] Consequently the author of works of narrative is not the narrator of these works (Martinez-Bonati in Cohn 126).

John Barth wrote about his two novels The Sot-Weed Factor and Giles Goat-Boy that they "imitate the form of the Novel" and they are written by "an author who imitates the role of the Author" (Barth in Richter 84). Roth is not very far from this approach.

We are confronted to the text of a text. This distinction is essential because Zuckerman's narration is the medium through which any description of reality, any character's point of view or linguistic bravado has to go. Every embedded story is embedded into Zuckerman's master narrative, which is far from being a neutral zone. It is a familiar subjective entity which colors everything it touches.

Roth and the concept of conflict

Before studying the implications of such a device for the reader and his quest for meaning, we may speculate on Roth's motivations. His use of Zuckerman in the eighties was quite clear: he saw his main character as a conflict-magnet. Nathan was in trouble because he was drawn to people in trouble - or, at least, they were drawn to him: "Roth's protagonists, like Bellow's, are nothing if not alive and in trouble" (Halio 5). Here are some various quotations from Roth, summing up his manifesto:

My fiction is about people in trouble (Searles 2).

Thinking back over my work, it seems to me that I've frequently written about what Bruno Bettelheim calls "behavior in extreme situations" (Searles 65).

A character in his predicament is what I have to begin with (Searles 163).

It was too big [Portnoy's Complaint's success] ... A few weeks after publication, I boarded a bus ... and holed up at Yaddo, the writer's colony, for three months. Precisely what Zuckerman should have done after Carnovsky - but he hung around, the fool, and look what happened to him. He would have enjoyed Yaddo more than he enjoyed Alvin Pepler. But it made Zuckerman Unbound funnier keeping him in Manhattan, and it made my own life easier, not being there (Searles 176).

21 It is my contention that the dynamics of Roth's work stems from conflict. In every nook and cranny of his fiction, strife is brewing ${ }^{12}$ in its content and in its form. Antagonism is the fabula's engine. Zuckerman Bound and The Counterlife introduce relentless verbal fighters, Alvin Pepler (Zuckerman Bound) being their leader. It offers Roth the opportunity to demonstrate his remarkable linguistic skills, consisting mainly in producing characters who are compulsive talkers without sensible things to say. Pepler's lengthy tirades on quiz shows and the fall of Newark represent Roth's linguistic trademark. We are snowed under with endless hyperboles yielding an incredible energy, created from the mix of streetwise vernacular and literary consistence. A perfect example can also be found in Operation Shylock with Roth's double, Moishe Pipik, spokesman of a new diaspora encouraging Jews to leave Israel and settle back in Eastern Europe where, of course, they would be most welcome. The author offers his character numerous pages to explain his theory. Once again, what matters is not what is said but the energy produced. Deception's narrator, an author named Philip, regrets the dullness of London Jews and longs for the energy of New York Jews: 
Jews with force, I'm talking about. Jews with appetite. Jews without shame. Complaining Jews who get under your skin. Brash Jews who eat with their elbows on the table. unaccommodating Jews, full of anger, insult, argument, and impudence. New York's the real obstreperous Zion, whether Ariel Sharon knows it or not (Roth, Deception 198).

Of course, there are many other aspects to New York's Jewish community, but this is the one Roth as a novelist is interested in, and it has put him occasionally into trouble, people having difficulty understanding that the Jews he portrays in his fiction are not a realistic description of a whole community but a bunch of characters used to keep the engine roaring. And beyond the verbal dynamics, Roth's narrative scheme is based on a series of oppositions, conflicts between his group of available characters. It would be too long to show all the antagonistic combinations, but we can nevertheless mention some of the most important ones. As far as the narrative dynamics is concerned, the American trilogy is not different from Zuckerman Bound for example. The concept of family feud is present in the overwhelming majority of Roth's novels. The Ghost Writer and Zuckerman Bound sometimes give the impression of being only about this topic with, as a climax, Zuckerman's father calling his son a "bastard" just before passing away. Another powerful and intrusive father, Lou Levov, can be found in American Pastoral, but the idea of breaking away from one's family is also omnipresent in I Married a Communist and The Human Stain. This source of conflict has been used by Roth throughout the years. The individual versus society is another source which, once again, is a common denominator of the Zuckerman novels in the eighties and the trilogy. Whatever the combination, the idea is to find a nemesis for a character, and this is where the main difference between Zuckerman Bound and the American trilogy lies: Roth used to imagine a nemesis for Nathan; now he is appointing Zuckerman to find Lou Levov, Ira Ringold or Coleman Silk a nemesis, and he finds them in spades. Roth's novels are mimesis of conflicts maybe because, as the narrator of The Anatomy Lesson (Zuckerman?) puts it, "the experience of contradiction is the human experience" (Roth, Zuckerman Bound 467). Similarly, we can quote a passage from The Human Stain which almost speaks for itself:

'You know how European literature begins ... With a quarrel. All of European literature springs from a fight'. And then he picked up his copy of The Iliad and read to the class the opening lines. 'Divine Muse, sing of the ruinous wrath of Achilles ... Begin where they first quarreled, Agamemnon the King of men, and great Achilles' (Roth, Human Stain 4).

Strife, antagonism, oppositions, conflict are Roth's fuel. To put it differently, they keep the story going. But they do not only take place inside the fiction, they also happen "around it," at the interpretative level. As far as the postmodern reader is concerned, being in conflict with the work she/he reads is a very common situation since being deprived of unity, certainty or meaning is her/his daily quandary. Arguing that Roth is quintessentially postmodern would be too long, ${ }^{13}$ so this is something we will take for granted, but his work seems to match in an obvious way every definition of postmodernism, and particularly Richard Rorty's:

The word 'postmodernism' has been rendered almost meaningless by being used to mean so many different things [...]. Various as the definitions of 'postmodern' are, most of them have something to do with a perceived loss of unity [...]. The sense that everything has recently fallen to pieces results from combining a renunciation of the traditional theologicometaphysical belief that Reality and Truth are One that there is One True Account of How Things Really Are - with the inability to believe that things are going to get better: that history will someday culminate in 
the universal adoption of egalitarian, democratic customs and institutions (Rorty 262).

24 The Counterlife is a perfect fictional illustration of such a definition with the final impossibility to find, without having any lingering doubts, a unifying center, a mastertext for all the contradictory chapters. One can easily understand that the role of the reader is not to make sense of the novel in the traditional way, but rather to accept the uncertainty and to learn that fiction, in the same way as life, is at best a series of misconceptions, misrepresentations and mistakes. Or, in the words of Zuckerman himself:

The fact remains that getting people right is not what living is all about anyway. It's getting them wrong that is living, getting them wrong and wrong and wrong and then, on careful reconsideration, getting them wrong again. That's how we know we are alive: we're wrong (Roth, Pastoral 35).

This quotation is not drawn from The Counterlife, but from the first novel of the American trilogy, American Pastoral, in which complexity and chiefly uncertainty are as vivid but in a less visible way. The consequences of Zuckerman's role in it have yet to be explained, but we can however mention the numerous lapses of memory the characters complain of, these lapses offering unstable recollections, doubtful versions, unrecovered facts. Chapters connecting seamlessly are not a guarantee of clarity or certainty. When a whole work's mimesis is based on its characters' memory, and the latter seems to go to pot, the reader is left contemplating his own aspirations and their irrelevance. According to psychoanalytic theory, we find "in the literary work the kind of thing we characteristically wish or fear the most," and we "ward off any potential threat that a narrative poses to psychic equilibrium" (Martin 157). Without jeopardizing the reader's sanity, novels like The Counterlife and Operation Shylock question the whole concept of sanity and are a serious test of the reader's defense mechanisms. So is the American trilogy, but more subtly, with Zuckerman as its most unsettling tool.

Roth and Zuckerman

So far, Zuckerman's narratological evolution has been studied, his seminal role in the American trilogy emphasized and the idea of conflict as Roth's main dynamic insisted on. We have seen that, inside the mimesis, Zuckerman is often the one who attracts antagonisms (in the eighties) or is drawn to others' conflicts (in the nineties). We still have to analyze how Roth uses the figure of Zuckerman to antagonize his own reader and how Zuckerman's authorial narration threatens the American trilogy's mimetic balance.

Like many writers, Roth has always been appalled by some readers' propensity to make no distinction between the author and a look-alike character. It is true that it has cost him dearly, and insisting on this distinction has been like a crusade to him, but it has also been a great source of provocation. As mentioned before, he went as far as to call a character Philip Roth in one of his novels. Moreover, Zuckerman doesn't seem to be that different from what Roth has been telling about himself. ${ }^{14}$ The contrast between his "crusade" and his use of characters having similar traits to his has set some critics' teeth on edge. ${ }^{15}$ One can suppose that this type of reaction is not very far from what Roth has been looking for. Indeed, it seems quite in keeping with the antagonistic logic of his work. Roth then uses Zuckerman as a trap for the reader's lower instincts. He toys with the "conflicts between the beliefs expressed [by Zuckerman for instance] and the beliefs we hold and suspect the author of holding" (Booth 73). Zuckerman is then 
the perfect tool to create dynamic tension; he is looking for trouble inside the fiction, but he is also an "interpretative lure". Thomas Pughe has emphasized the comic side of that tension:

Working the inter-subjective situation of the contemporary artist into comic form constitutes Roth's creative achievement [...]. The author actually invites or even provokes the reference to his own career. His comic "Künstler-Roman" is a symptom of the very process it re-presents. Roth's obvious 'plundering' manoeuvres his readers into a position similar to that of the (fictional) participants, including the writer-hero, who are engaged in textual controversies in his novels, because such 'plundering' simultaneously narrates and anticipates the concern of readers and reviewers with the difference between biography and novel, 'reality' and 'fiction' (Pughe 120-122).

So, what is the reader supposed to do with this Zuckerman?

Paradoxically, with all these postmodern techniques and wrong-footing, Roth has created a perfectly realistic character in a way similar to Twain's or Cervantes's, who "naturalized" their character "by juxtaposing him with the prior book in which he appears" (Martin 67). The more sophisticated the character, the more realistic he is. And in the American trilogy, Zuckerman reaches the peak of his career. He looks more like his creator than he has ever done before, and his narratological sophistication couldn't be better since he is the alleged author of three books in a row. How can a character be more powerful? Yet his presence has been hardly noted in the trilogy, maybe because the mere content of the novels has held the majority of readers and critics spellbound.

Let's take a closer look at American Pastoral, the one novel of the trilogy in which Zuckerman's presence seems the most subdued. Roth justified his character's discretion in an interview:

Zuckerman was my insider, my knowledgeable wedge into the Swede's life, who somehow gave me the freedom to know him. On Page 90 I jettisoned Zuckerman he was no longer necessary (Roth in McGrath 1).

So Swede's life story is supposed to come out of Zuckerman's imagination although the latter has been jettisoned? What does it mean? Zuckerman is the narrating source, but one shouldn't pay any attention to it or, as a second solution, there is no difference between Roth's and Zuckerman's imagination. Both solutions are far from being satisfactory. Of course, it is the author's word against the reader's. Who is he/she to question the author's intentions when they are so clearly expressed? There is a simple answer to that: as a reader, and even more as an academic, one is entitled to question the way meaning can be inferred from a work of fiction. Distrusting the author is a duty, even more in these postmodern and unreliable times.

31 As a distrusting reader, I would like to draw attention to a pivotal passage of American Pastoral. It is not blindingly obvious. One can even skim through it without realizing that something important has been missed. The reader is halfway through the narrative of Swede Levov's life and the narrator is once again getting down to the specifics of Swede's psychology: "And because even though he hadn't liked it one bit he did not believe it was his right blah-blah blah-blah blah, because ..." (Roth, Pastoral 252). It sounds like an alarm clock, drawing the reader out of his mimetic dream. No, this novel is not an exact picture of reality and, yes, there is at least one subjective barrier between the text and us. The whole point of American Pastoral, what makes it such a fascinating book, is not the fact that one is reading a portrait of a peaceful father who is 
prey to a family upheaval. The possible heart of the matter is the tension between that character and a narrator who is just at the opposite end on the psychological spectrum. The underlying question of the novel is this: how can a character as complex as Zuckerman be interested in such an insignificant personality? The last two thirds of the novel answer this question. Roth makes Zuckerman reinvent Levov, and also makes him find what Roth has always been interested in and what does not seem to be there at first sight - namely tension, conflict, chaos, mayhem. And once again, Zuckerman, the antagonistic machine, is up to the task. This is also what he does in the next two novels, even if with Ira Ringold and Coleman Silk antagonisms are handed to Zuckerman on a silver platter. The implication of taking the aesthetic decision to give the American trilogy the perfect appearance of books written by Zuckerman is twofold. Firstly, Roth is able to carry on playing his identity game in a much more complex manner, since he seems to disappear totally as an author; on the other hand, his narrator seems to be closing the gap, resembling him more and more. Secondly, it conveys, whether it was the author's primal concern or not, a narrative complexity through several layers of narration: Roth making Zuckerman write a story out of Swede's first-degree then secondary-degree life-story which itself includes embedded stories. It is axiomatic that the more visible the diegesis, the less reliable the mimesis. Through such a degree of sophistication, the reader is reminded that "literature is something other than reality" (Hamburger 9).

of course, one can decide to overlook this blah-blah-blah, to look away from the narrative device - which is quite understandable if the reader is opening a Roth novel for the first time and has never heard of Zuckerman before - and simply enjoy this compelling read. There are many reading degrees, but the one we are aiming at tries to take as much as possible into account. It is true that "even among the most jaded readers - academics - the majority still attempts to read as authorial audience" (Rabinowitz 30). Reading "only diegetically" might simply be an impossible experience which would be devoid of pleasure, anyway. But experienced readers are expected to go back and forth between diegesis and mimesis, both changing each other as the wary reader proceeds with his reading. If not, how is one supposed to answer American Pastoral's final question: "And what is wrong with their life? What on earth is less reprehensible than the life of the Levovs?" (Roth, Pastoral 467). To comprehend satisfactorily the ironical complexity of the question, the reader needs to bring Nathan urgently back into the picture. Zuckerman's blah-blah-blah should be heeded.

\section{BIBLIOGRAPHY}

Bal, Mieke. Narratology, Introduction to the Theory of Narrative. Toronto: University of Toronto Press, 1985.

Booth, Wayne C. A Rhetoric of Irony. Chicago: University of Chicago Press, 1974.

Cohn, Dorrit. The Distinction of Fiction. Baltimore: The Johns Hopkins University Press, 1999. 
Danziger, Marie A.. Text/Countertext, Postmodern Paranoia in Samuel Beckett, Doris Lessing, and Philip Roth. New York: Peter Lang, 1996.

Epstein, Joseph. “What does Philip Roth want?”. Commentary. Vol. 77, No. 1. (January 1984): 620-27.

Franzen, Jonathan. How to be Alone. New York: Farrar, Strauss and Giroux, 2002.

Genette, Gérard. Nouveau Discours du Récit. Paris: Editions du Seuil, 1983.

Halio, Jay L. Philip Roth Revisited. New York: Twayne Publishers, 1992.

Hamburger, Käte. The Logic of Literature. Bloomington: Indiana University Press, 1993.

McGrath, Charles. “Zuckerman's Alter Brain.” The New York Times Book Review. 7 May 2000: 8-10.

Martin, Wallace. Recent Theories of Narrative. Ithaca: Cornell University Press, 1986.

Podhoretz, Norman. “The Adventures of Philip Roth.” Commentary. Vol. 106, No. 4. (October 1998): 25-36.

Pughe, Thomas. Comic Sense: Reading Robert Coover, Stanley Elkin, Philip Roth. Basel: Birkhäuser, 1994.

Rabinowitz, Peter J. Before Reading: Narrative Conventions and the Politics of Interpretation. Columbus: Ohio State University Press, 1988.

Richter, David H. Narrative/Theory. White Plains, NY: Longman, 1996.

Rorty, Richard. Philosophy and Social Hope. Harmondsworth: Penguin, 1999.

Roth, Philip. My Life as a Man. 1974; New York: Vintage, 1993.

---. The Counterlife. Harmondsworth: Penguin, 1988.

---. The Facts: A Novelist's Autobiography. Harmondsworth: Penguin, 1989.

---. Zuckerman Bound, A Trilogy [The Ghost Writer (1979), Zuckerman Unbound (1981), The Anatomy Lesson (1984)] and Epilogue [The Prague Orgy (1985)]. Harmondsworth: Penguin, 1989.

---. Deception. London : Vintage, 1990.

---. Operation Shylock. London: Jonathan Cape, 1993.

---. Sabbath's Theater. London: Jonathan Cape, 1995.

---. American Pastoral. London: Jonathan Cape, 1997.

---. I Married a Communist. New York: Houghton Mifflin Company, 1998.

---. The Human Stain. London : Jonathan Cape, 2000.

Searles, George J. (ed.). Conversations with Philip Roth. Jackson: University Press of Mississippi, 1992.

\section{NOTES}

1. American Pastoral (1997), I Married a Communist (1998), The Human Stain (2000).

2. Bal, Narratology 142. To refer to events or characters appearing in an embedded narrative, Gérard Genette uses the term "intradiégétique" (Figures III 238).

3. "Narrateur extradiégétique" (Genette, Figures III 252). 
4. "Homodiégétique" (Genette, Figures III 252).

5. "A long time, I thought I had abandoned him [Zuckerman] after "The Prague Orgy" (Roth in McGrath 1).

6. Second-degree make-believe since any fiction pretending to mirror reality can be dubbed first-degree make-believe, but in the specific case of Swede's so-called lifestory, we know it is invented by someone who has been invented.

7. See Bal 26.

8. Someone who tells the story or is a witness to it without being at the front of the stage, like Dr. Watson (Genette, Nouveau Discours du Récit 69).

9. Theorists like Hayden White maintain that every writing is a narrative and though this is quite a sensible view, we can argue that the narrative techniques of an article and a work of fiction are not the same and that, above all, the reference (reality $v s$ a fictional world) is not the same. Dorrit Cohn has made this point with great talent in her excellent book, The Distinction of Fiction.

10. One can argue that he is the undeclared, third-person author-narrator of his own story.

11. Although this is something too complex to be developed thoroughly here, the whole concept of style must be revisited. Talking about an author's style is acceptable only in the case of an autobiography. Fiction implies a narrator whose style has to be invented. An author whose style is similar, whatever the narrative situation, is an author who has played the fictional game only partially.

12. This theory has been developed at greater length in my thesis: "Figures et Enjeux du Récit: la Non-congruence dans la Série Zuckerman de Philip Roth" (Narrative Figures and Narrative Stakes : Non-Congruence in Philip Roth's Zuckerman Novels).

13. I have dedicated a whole chapter of my thesis to it, quoting the works of Hutcheon, Lyotard, Russel, McHale, Smyth or Rorty.

14. Actually, the difference is thinner than it used to be, since Zuckerman is now a recluse, like Roth, living an isolated life in New England.

15. "Moreover, I was irritated by the literary games Roth took to playing in some of his later, "postmodern" novels. These games consisted in virtually forcing the reader into seeing something as autobiographical and then implicitly rebuking him for doing so (how could anyone be so stupid as not to understand that art "transmutes" reality?)" (Podhoretz 33); "Roth has spoken of readers getting a "voyeuristic kick" from reading his autobiography into his books. I think "voyeuristic kick" is exactly the correct phrase, and my first response to it is that, if a writer doesn't wish to supply such kicks, perhaps he would do better not to undress before windows opening onto thoroughfares" (Epstein 64).

\section{INDEX}

Keywords: Postmodernism, Philip Roth, Nathan Zuckerman, Narratology, Mimesis, Irony, Narrative conflict 
AUTHOR

ARNAUD SCHMITT

Arnaud Schmitt, Montesquieu University (Bordeaux IV) 